\title{
PRODUCTION OF ULTRAPURE FERROSILICON CHROME WITH CONTROLLED CONTENTS OF CARBON AND OTHER CHEMICAL ELEMENTS FOR MANUFACTURING OF INNOVATIVE METALLIC MATERIALS
}

\author{
Bolesław MACHULEC ${ }^{1}$, Stanisław GIL², Wojciech BIALIK³ ${ }^{3}$ Sławomir KOZŁOWSKI ${ }^{4}$ \\ Silesian University of Technology, Faculty of Materials Engineering and Metallurgy, Katowice, Poland, EU \\ 1․oleslaw.machulec@polsl.pl, ${ }^{2}$ stanislaw.gil@polsl.pl, ${ }^{3}$ wojciech.bialik@.polsl.pl
}

https://doi.org/10.37904/metal.2019.800

\begin{abstract}
Production of innovative types of steel and other metallic materials requires the composition to contain, in addition to iron, other chemical elements that influence desired properties of the alloy. Alloy additions are mainly introduced due to the use of appropriate ferroalloys in the production process. The paper presents effects of complex ultrapure $\mathrm{FeSiCr}$ alloy production process.
\end{abstract}

Keywords: Ferrosilicon, submerged arc furnace, casting ladles, improving purity of alloy

\section{INTRODUCTION}

Production of modern steels, particularly high-alloy types, is strictly related to the use of ferroalloys in the manufacturing process. Among these steels, the corrosion-resistant ones are especially important. Their production, following a temporary reduction (by about $12 \%$ ) to 25 million Mg/year in 2009, was constantly growing to reach approximately 35 million Mg/year in 2014. The most intensive manufacturing increase was observed for austenitic chromium-manganese steels: from 1 million Mg/year in 2001 to 4 million Mg/year in 2010; these are 200 series steels according to AISI [1]. Steels characterised by a ferritic structure and a low carbon content belong to another popular type of these metals. During their production, the essential issue is a careful selection of charge materials and alloy components in respect of carbon contents. These modern types of steel require the ferrochrome alloy with a very low carbon content. It is also used for Duplex steel production, of which the most popular types are: 1.4362, 1.4410, 14460, 14462. They contain more than $20 \%$ of chromium while the carbon content is limited to $0.03 \%$. A low carbon content minimises formation of chromium carbides that lead to depletion of chromium in the regions next to the grain boundaries which results in poorer resistance to intergranular corrosion [2]. In the case of other alloy component carriers of these steels, such as ferromanganese and ferronickel, the carbon content is also strictly reduced. The low carbon content in liquid steel provides specific conditions that are necessary for its deoxidation. Therefore, the aim is production of ferroalloy that contains, in addition to iron and chromium, silicon for metal bath deoxidation. An answer to the existing demand is production of ultrapure ferrosilicon chrome ( $\mathrm{FeSiCr}$ ) with controlled contents of carbon, nitrogen, oxygen and hydrogen. Another important branch of modern industry that uses ferrochrome alloys with a low carbon content is welding engineering. This type of alloy is used for production of welding materials meant for joining steels that are difficult to weld. Basic electrodes for this process, such as OK 67.45 or ES 18-8-6B, contain: $18.5 \% \mathrm{Cr}, 8.5 \% \mathrm{Ni}, 6 \% \mathrm{Mn}, 0.5 \% \mathrm{Si}$ and only $0.1 \% \mathrm{C}$. Metal charge that is used for their production requires the same restrictive limitations of carbon and gaseous components as those for the above mentioned steels.

\section{CHARGE MATERIALS}

The process of complex FeSiCr smelting is conducted under industrial conditions at Re Alloys, Łaziska Górne, in submerged arc furnaces nos. 17 and 18, using a continuous, slag-free method where the chromium carrier is high-carbon (processing) ferrochrome, the silicon carrier is quartzite and the reducer is hard coal [3]. Moreover, to improve gas permeability of the charge bed and to correct substrate resistance, wood chips are 
added. In Tables 1-3, chemical compositions of processing ferrochrome and quartzite, physicochemical properties of used coals and wood chips as well as the chemical composition of mineral residue from used coals and wood chips in the process of complex FeSiCr alloy smelting are presented.

Table 1 Chemical compositions of processing ferrochrome and quartzite [3]

\begin{tabular}{|c|c|c|c|c|c|c|c|c|c|c|c|c|}
\hline \multicolumn{6}{|c|}{ Processing ferrochrome } & \multicolumn{7}{|c|}{ Quartzite } \\
\hline \multicolumn{6}{|c|}{ Chemical element contents, wt. \% } & \multicolumn{7}{|c|}{ Component contents, wt. $\%$} \\
\hline $\mathrm{Cr}$ & $\mathrm{Si}$ & C & $\mathrm{P}$ & $\mathrm{S}$ & $\mathrm{Fe}$ & $\mathrm{SiO}_{2}$ & $\mathrm{Al}_{2} \mathrm{O}_{3}$ & $\mathrm{Fe}_{2} \mathrm{O}_{3}$ & $\mathrm{CaCO}_{3}$ & $\mathrm{TiO}_{2}$ & $\mathrm{P}$ & $\mathrm{S}$ \\
\hline $\min 66.00$ & 1.5 & $\begin{array}{l}\text { Max } \\
8.5\end{array}$ & $\begin{array}{l}\text { Max } \\
0.025\end{array}$ & $\begin{array}{l}\text { Max } \\
0.05\end{array}$ & $\begin{array}{l}\text { the } \\
\text { other }\end{array}$ & $\begin{array}{l}\text { Min } \\
98.5\end{array}$ & $\begin{array}{l}\text { Max } \\
0.7\end{array}$ & 0.207 & 0.048 & 0.062 & $\begin{array}{l}\text { Max } \\
0.003\end{array}$ & $\begin{array}{l}\text { Max } \\
0.01\end{array}$ \\
\hline
\end{tabular}

Table 2 Physicochemical properties of used coals and wood chips [4]

\begin{tabular}{|c|c|c|c|c|c|c|c|}
\hline \multirow{2}{*}{\multicolumn{3}{|c|}{ Parameter }} & \multicolumn{3}{|c|}{ Hard coal } & \multicolumn{2}{|c|}{ Wood chips } \\
\hline & & & \multirow{2}{*}{$\begin{array}{c}\text { KWK } \\
\text { Wujek }\end{array}$} & \multirow{2}{*}{$\begin{array}{c}\text { KWK } \\
\text { Chwałowice }\end{array}$} & \multirow{2}{*}{$\begin{array}{c}\text { KWK } \\
\text { Wieczorek }\end{array}$} & \multirow{2}{*}{ Pine } & \multirow{2}{*}{ Beech } \\
\hline Name & Symbol & Unit & & & & & \\
\hline Humidity & $W_{t}^{r}$ & wt. $\%$ & 3.92 & 7.09 & 5.4 & 55.8 & 46.0 \\
\hline Ash content & $A^{r}$ & wt. $\%$ & 3.36 & 5.94 & 4.3 & 0.3 & 0.8 \\
\hline Volatile matter content & $\mathrm{V}^{\mathrm{r}}$ & wt. $\%$ & 30.78 & 33.47 & 31.61 & 81.3 & 84.0 \\
\hline Hard coal & $\mathrm{C}_{\text {fix }}$ & wt. $\%$ & 61.94 & 53.50 & 58.70 & 11.97 & 14.1 \\
\hline Sulphur content & $\mathrm{S}_{t^{r}}$ & wt. $\%$ & 0.47 & 0.64 & 0.33 & & \\
\hline Calorific value & $W_{d t^{r}}$ & $\mathrm{MJ} / \mathrm{kg}$ & 30.96 & 27.790 & 30.36 & 18.4 & 19.2 \\
\hline Volatile matter content & $V^{\text {daf }}$ & wt. \% & 33.2 & 38.49 & 35.47 & & \\
\hline
\end{tabular}

Table 3 Chemical composition of mineral residue from used coals and wood chips [4]

\begin{tabular}{|c|c|c|c|c|c|c|}
\hline \multirow{2}{*}{\multicolumn{2}{|c|}{$\begin{array}{l}\text { Chemical composition } \\
\text { of mineral residue }\end{array}$}} & \multicolumn{3}{|c|}{ Hard coal } & \multicolumn{2}{|c|}{ Wood chips } \\
\hline & & \multirow{2}{*}{$\begin{array}{r}\text { KWK } \\
\text { Wujek } \\
34.59 \\
\end{array}$} & \multirow{2}{*}{$\begin{array}{c}\text { KWK } \\
\text { Chwałowice }\end{array}$} & \multirow{2}{*}{$\begin{array}{c}\text { KWK } \\
\text { Wieczorek } \\
15.6 \\
\end{array}$} & \multirow{2}{*}{$\begin{array}{l}\text { Pine } \\
28.25\end{array}$} & \multirow{2}{*}{$\begin{array}{l}\text { Beech } \\
30.47 \\
\end{array}$} \\
\hline $\mathrm{SiO}_{2}$ & wt.\% & & & & & \\
\hline $\mathrm{Al}_{2} \mathrm{O}_{3}$ & wt.\% & 24.37 & 24.16 & 10.3 & 4.58 & 3.63 \\
\hline $\mathrm{Fe}_{2} \mathrm{O}_{3}$ & wt.\% & 15.24 & 16.26 & 13.0 & 5.02 & 2.14 \\
\hline $\mathrm{CaO}$ & wt.\% & 7.12 & 9.74 & 18.05 & 36.54 & 29.60 \\
\hline $\mathrm{MgO}$ & wt.\% & 4.77 & 5.06 & 10.4 & 8.15 & 3.67 \\
\hline $\mathrm{Na}_{2} \mathrm{O}$ & wt.\% & 1.97 & 2.05 & 4.34 & 1.2 & 0.35 \\
\hline $\mathrm{K}_{2} \mathrm{O}$ & wt.\% & 1.41 & 1.09 & 0.72 & 6.26 & 10.27 \\
\hline $\mathrm{SO}_{3}$ & wt.\% & 7.22 & 8.59 & 19.35 & 0.58 & 1.71 \\
\hline $\mathrm{TiO}_{2}$ & wt. $\%$ & 1.26 & 0.72 & 0.4 & 0.1 & 0.22 \\
\hline $\mathrm{P}_{2} \mathrm{O}_{5}$ & wt.\% & 0.75 & 1.13 & 0.73 & 0.65 & 2.68 \\
\hline $\mathrm{BaO}$ & wt.\% & 0.38 & & & 0.04 & $0 . .35$ \\
\hline $\mathrm{Mn}_{3} \mathrm{O}_{4}$ & wt.\% & & 0.15 & 0.24 & 0.2 & 2.13 \\
\hline $\mathrm{SrO}$ & wt.\% & 0.24 & & 0.73 & 0.01 & 0.35 \\
\hline
\end{tabular}


According to the demands, raw materials are replenished with proper amounts of ferriferous materials: scale yielded from heat treatment of steel that mainly contains $\mathrm{FeO}$ and $\mathrm{Fe}_{2} \mathrm{O}_{3}$.

\section{REDUCTION PROCESSES AND ELECTRICITY CONSUMPTION}

Charge materials in the furnace bath are heated by electric current. In the upper layer of the charge material, thermal energy is released as a result of electric current flow through the charge of appropriate resistance. Below, near the furnace hearth, heat is released by the electric arc between the electrode tips and liquid alloy. In the presence of carbon from reducers, silicon dioxide is gradually conversed to silicon metal and $\mathrm{CO}$ is released. Analogical reactions are observed between iron oxides from ferriferous materials that are reduced to form liquid iron. They can be described by an overall reaction [4]:

$\mathrm{SiO}_{2}+a C+b \mathrm{FeO}=\eta_{S i} \mathrm{Si}+b \mathrm{Fe}+\left(1-\eta_{S i}\right) \mathrm{SiO}+a C O$

where: $a$ and $b$ are coefficients of the overall reaction that depend on the composition of the alloy being manufactured; $\eta$ si denotes silicon yield that depends on furnace operating conditions and technological experience of the operators. The silicon yield is determined as the ratio of silicon weight to silicon weight in the raw materials. At a high temperature that is generated by the electric arc, pieces of processing ferrochrome (contained in the charge material) also melt and add chromium to the yielded alloy. The silicon yield $\eta$ si that is observed in the process of FeSiCr production is comparable to the yield resulting from conventional ferrosilicon alloy manufacturing, while the chromium yield exceeds $95 \%$. The yields of silicon and chromium, determined based on the process data, are presented in Figure 1.

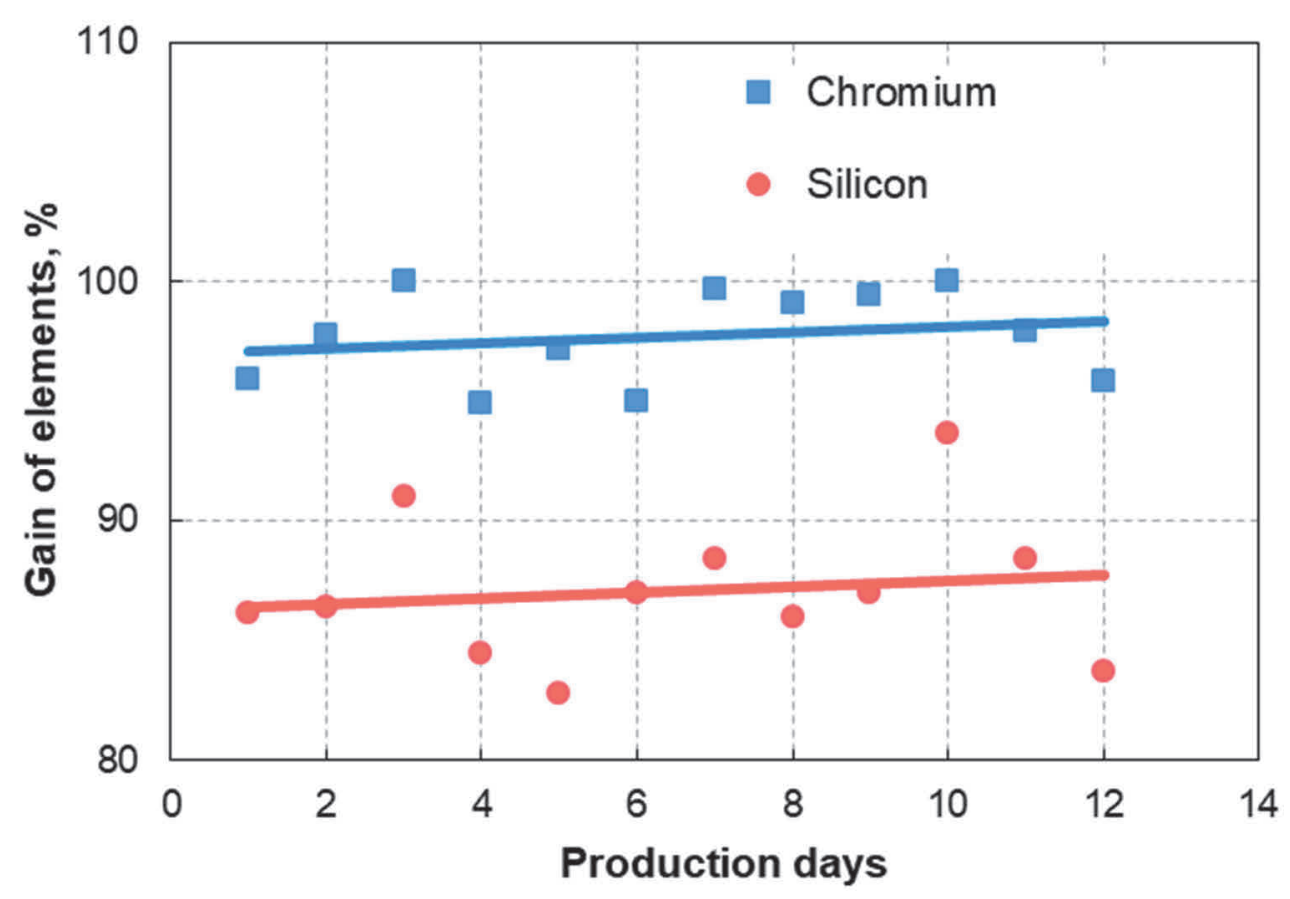

Figure 1 The yields of silicon and chromium in the FeSiCr production process

The silicon yield affects electricity consumption in the process. During ferrosilicon production, higher $\eta$ sivalues lead to reduction of electricity consumption [5;6]. Analogical trends are observed for the process of complex $\mathrm{FeSiCr}$ alloy production. Recorded values are presented in Figure $\mathbf{2}$. 


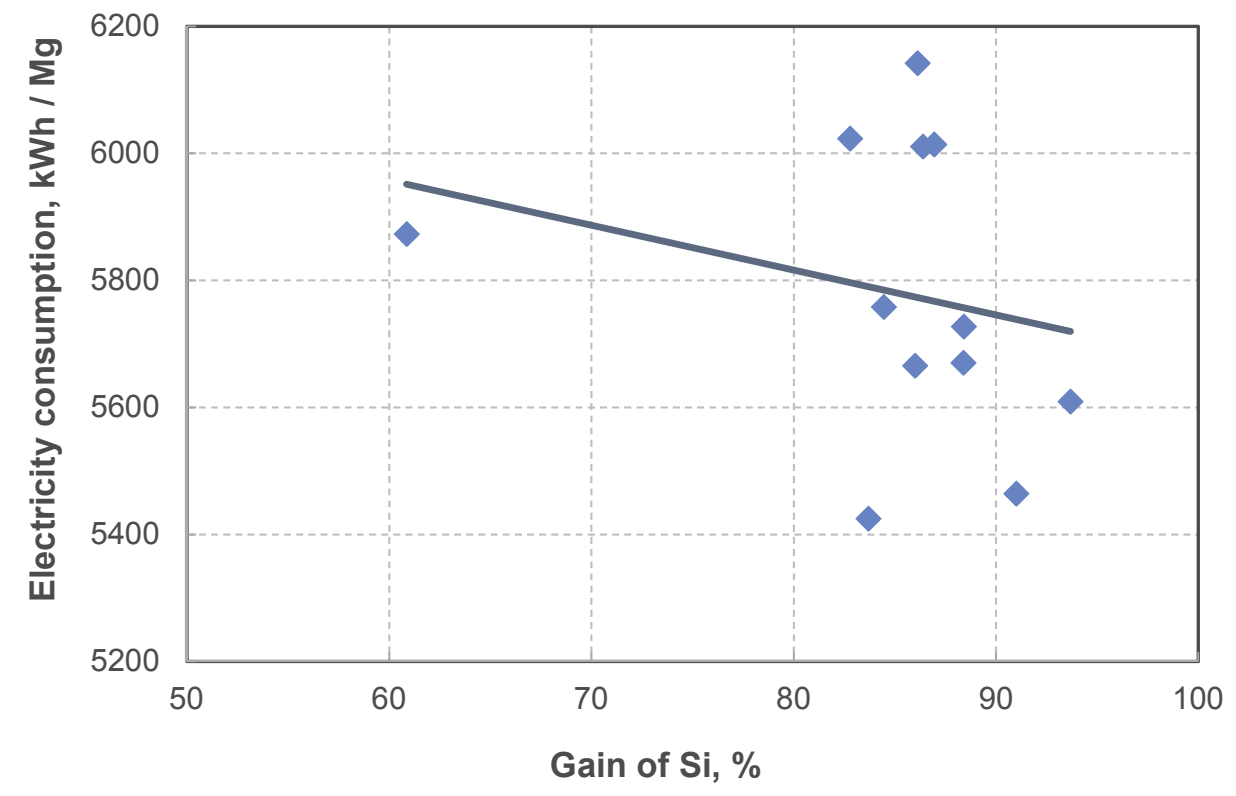

Figure 2 Electricity consumption in the function of Si yield

The electricity consumption during FeSiCr production for consecutive days is illustrated in Figure 3. Its mean long-term value is $5800 \mathrm{kWh} / \mathrm{Mg}$ of the alloy and the silicon yield is $87 \%$.

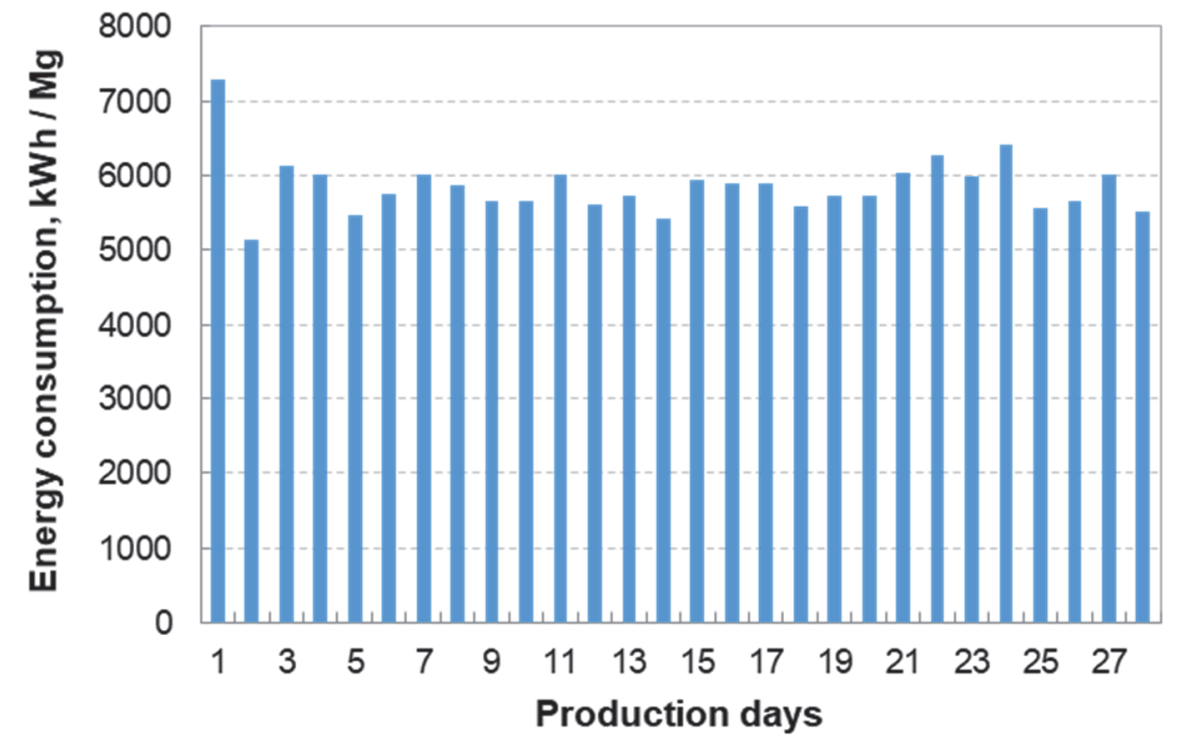

Figure 3 Electricity consumption during 28 production days

Liquid alloy is periodically, every 2 hours, released from the furnace through the tapping hole to the tapping ladle and then transferred into the refining ladle. The refining process lasts about 90 to 120 minutes and it aims at removing excess carbon and other undesired inclusions from the alloy [7]. The refining ladle is located on a supporting construction with the operating bridge meant for metal bath temperature measurements and charging microsilica onto the liquid metal surface. The process of transferring the refined alloy into cast-iron ingot moulds is illustrated in Figure 4. 


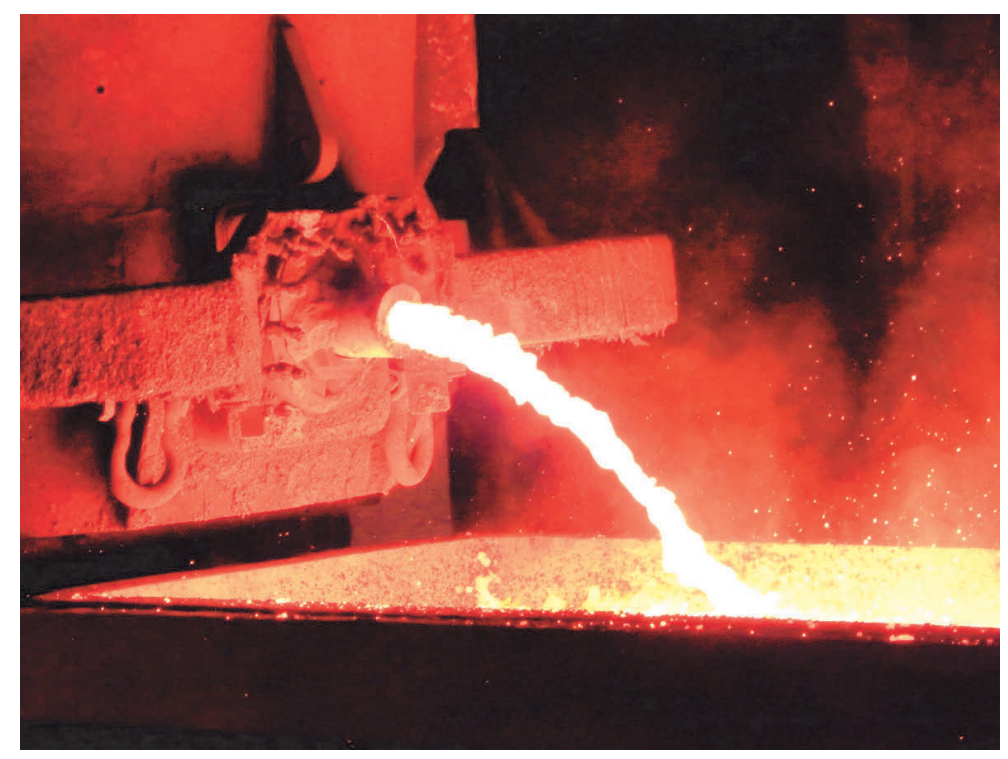

Figure 4 The process of FeSiCr transfer into ingot moulds

476 post-refining $\mathrm{FeSiCr}$ smelting products were transferred into the ingot moulds. An average carbon content recorded following the alloy refining during the whole stage of investigations was $0.0232 \mathrm{wt} . \%$. A distribution of obtained carbon contents is presented in Figure $\mathbf{5}$.

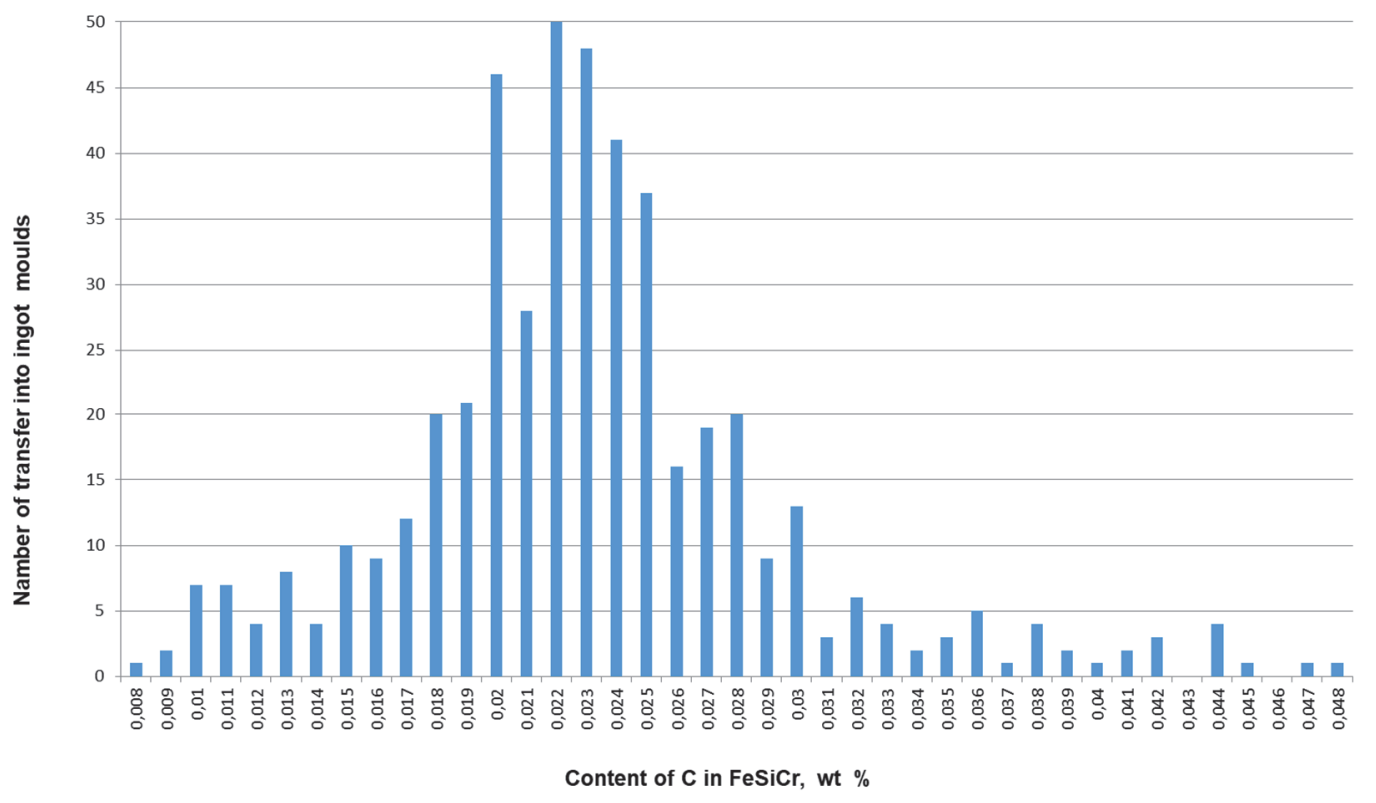

Figure 5 Distribution of the recoreded carbon contents during the refined $\mathrm{FeSiCr}$ melts [3]

During the refining process (lasting about 90 to 120 minutes), SiC (that contains carbon) is transferred onto the liquid metal surface (due to a significant density difference compared to $\mathrm{FeSiCr}$ ) and bound in microsilica. The process of refining can be intensified when the time is halved due to gas purging (using e.g. argon) as it is done in steelmaking processes [8]. For the metallurgical use of complex $\mathrm{FeSiCr}$ alloy, important issues are proper ratios of $\mathrm{Cr} / \mathrm{Fe}$ and $\mathrm{Si} / \mathrm{Fe}$ [9]. In the case of manufactured alloy, favourable ratios of $\mathrm{Cr} / \mathrm{Fe} \approx 2$ and $\mathrm{Si} / \mathrm{Fe} \approx 3$ were obtained. The $\mathrm{Si} / \mathrm{Fe}$ weight ratio, important in the processes of steel deoxidation, is analogical to that for the most popular ferrosilicon alloy FeSi75. 
Table 4 Average chemical composition of the refined ferrochrome

\begin{tabular}{|c|c|c|c|c|c|c|c|c|}
\hline \multicolumn{9}{|c|}{ Ferrochrome } \\
\hline \multicolumn{9}{|c|}{ Chemical element contents, wt. \% } \\
\hline $\mathrm{Cr}$ & $\mathrm{Si}$ & $\mathrm{Fe}$ & C & $\mathrm{P}$ & S & $\mathrm{N}$ & $\mathrm{O}$ & $\mathrm{H}$ \\
\hline 34.368 & 48.216 & 16.270 & 0.024 & 0.009 & 0.001 & 0.009 & 0.245 & 0.024 \\
\hline
\end{tabular}

\section{CONCLUSIONS}

1) Raw materials that were selected for the experiments and the conducted refining process resulted in the assumed alloy quality considering the basic elements: Cr min. $34 \%$ (weighted mean $34.24 \%$ ), Si min. $48 \%$ (weighted mean $48.20 \%$ ), Cr/Fe min. 2.0 (weighted mean $2.09 \%$ ).

2) The contents of undesired components in the alloy are considerably lower than acceptable P max. 0.02 $\%$ (weighted mean $0.009 \%$ ), S max. $0.02 \%$ (weighted mean $0.001 \%$ ).

3) The technological experiment findings showed a potential for production of $\mathrm{FeSiCr}$ with assumed quality, applying an innovative technology that uses silica fume as a factor that supports $\mathrm{FeSiCr}$ decarburization refining.

4) The experiments confirmed a potential for obtaining assumed technical and economic indicators in the form of silicon and chromium yields as well as electricity consumption in the $\mathrm{FeSiCr}$ production.

5) During the smelting and refining processes, the waste was mainly silica fume: $110 \mathrm{~kg} / \mathrm{Mg}$ of the refined FeSiCr (the planned indicator: 80 to $120 \mathrm{~kg} / \mathrm{Mg}$ ).

\section{ACKNOWLEDGEMENTS}

The authors acknowledge the support of research project "Innovative technology for the production of ferrosilicon with silicon content min. $75 \%$ and ultra-low carbon content max. $0.02 \%$ " (Project No POIR.01.01.01-00-0052/17), funded by the Intelligent Development Operational Program 2014-2020.

\section{REFERENCES}

[1] GASIK, M., [red.]: Handbook of Ferroalloys Theory and Technology. Waltham: Elsevier Ltd. (ButterworthHeinemann), 2013.

[2] DOBRZAŃSKI, Leszek A. Metaloznawstwo opisowe. Wydawnictwo Politechniki Śląskiej. Gliwice 2013.

[3] WYROBEK Alojzy, KOZŁOWSKI Sławomir Raport z projektu Rafinowany, ultraczysty żelazokrzemochrom o kontrolowanej zawartości węgla, azotu, tlenu i wodoru. Etap I i II, Re Alloys 2017 (not published)

[4] BIALIK W., GIL S., MACHULEC, B. Physicochemical parameters of carbon reducers for the ferrosilicon smelting process. METAL $2017-26^{\text {th }}$ International Conference on Metallurgy and Materials, Conference Proceedings. 2017 - January, pp. 126-132.

[5] ZUBOV, Viacheslav L., and GASIK, Mihail I. Electrometallurgy of ferrosilicon. Physical Chemistry and Technology. Dnepropetrovsk: System Technologies Publication, 2002.

[6] SCHEI, A.J., TUSET, J. Kr., TVEIT, H. Production of High Silicon Alloys. Trondheim, 1998.

[7] KLEVAN, O.S. Removal of $\mathrm{C}$ and SiC from Si and FeSi during ladle refining and solidification. PhD Thesis. Trondheim: The Norwegian University of Science and Technology, Department of Metallurgy, 1997

[8] MERDER, Tomasz, PIEPRZYCA, Jacek, WARZECHA, Marek, WARZECHA, Piotr. Application of high flow rate gas in the process of argon blowing through steel. Archives of Metallurgy and Materials. 2017. vol. 62, no. 2, pp. 905-910.

[9] KOSYREV, K.L., OLSEN, S.E., 1995. Silicon and carbon in chromium alloys. In: Proceedings of the Congress INFACON-VII. Trondheim, Norway, pp.329-338. 